\title{
Index of individual poems, pictures and collections
}

'After Death' (C. Rossetti) 203

'After Death' (Swinburne) 109-10, 115, 120-1, 124-6, 131-4

'Ask me no more' (Tennyson) 173, 182

Astarte Syriaca (D. G. Rossetti) 42-4

'As through the land at eve we went' (Tennyson) 173, 181

'At Home' (C. Rossetti) 203

'At Last' (Siddal) 100, 108-12, 118, 123-34, 207

Aurora Leigh (Barrett Browning) 46, 172-5, 179, 184-5, 191

Beata Beatrix (D. G. Rossetti) 33, $38-40,63$

'Bertha in the Lane' (Barrett Browning) 106

'The Birth-Bond' (D. G. Rossetti) 63, 71,73

The Blessed Damozel (D. G. Rossetti) 49

Boadicea Brooding over her Wrongs (Howitt) 155

Bocca Baciata (D. G. Rossetti) 30, 42

The Bridesmaid (Millais) 208

'Burd Helen' (border ballad) 110

'Casabianca' (Hemans) 104

'A Castaway' (Webster) 46

'The Chamois Hunter's Love' (Hemans) 190

Clerk Saunders (Siddal) 45, 89-93, 103, $113,133,145$

'The Cry of the Children' (Barrett Browning) 112
'Come down oh Maid' (Tennyson) 173, 179,190

'A Curse for a Nation' (Barrett Browning) 112

'The Dark Glass' (D. G. Rossetti) 63-4, 69-70, 73, 78

'Dead Love' (Siddal) 174-8, 181-3, 187-90

'Divided' (Ingelow) 204

'Dream Land' (C. Rossetti) 203-4

'Duriesdyke' (Swinburne) 109, 117-18, 121, 124, 129

'Early Death' (Siddal) 64-5, 77, 81

Ecce Ancilla Domini! (D. G. Rossetti) 39

Elizabeth Siddall (Howitt) 160

Elizabeth Siddall (Smith) 161

Elizabeth Eleanor Siddal (D. G. Rossetti) 24-5

'The Factory' (Landon) 104

'The Fause Lover' (border ballad) 110

The Forest Sanctuary (Hemans) 111

Found (D. G. Rossetti) 18-20, 30

The Gay Goshawk (Siddal) 113

'Genius in Beauty' (D. G. Rossetti) 63, 69,79

'Gladys and Her Island' (Ingelow) 154

Goblin Market (C. Rossetti) 8, 105, 112, 126, 209

'Gone' (Siddal) 199, 207, 228-30, 237-44, 248-9 
'He and She and Angels Three' (Siddal) 108, 113, 120-2, 127-30, 133-4

'Heart's Compass' (D. G. Rossetti) 63, $69,71,75-7$

'Heart's Hope' (D. G. Rossetti) 62-3, 69, 75-6

'Her Gifts' (D. G. Rossetti) 63, 69, 72, 77

'Home they brought her warrior, dead' (Tennyson) 143-4

The House of Life (D. G. Rossetti) 18, $22,28-9,32,45-50,57-62,66$, $68,72-3,76,80$

Isabella (Hunt) 223

Isabella, or The Pot of Basil (Keats) 236-51

Isabella (Millais) 223-5

Jenny (D. G. Rossetti) 46-7

'Johnie Scot' (border ballad) 110

'The King's Daughter' (Swinburne) 109-10, 115, 118-21, 124, 129-31, 134-5

'The Kiss' (D. G. Rossetti) 63, 66, 71, 75,78

'La Belle Dame Sans Merci' (Keats) 209-10, 215, 226-7, 231-4, 238-9, 242-6, 250-1

La Belle Dame Sans Merci (Siddal) 207-8

Lady Clare (Siddal) 143-9, 176

'Lady Geraldine's Courtship' (Barrett Browning) 105-6

Lady Lilith (D. G. Rossetti) 42

Lamia (Keats) 214, 226-36, 240, 246, 248

'The Landing of the Pilgrim Fathers in New England' (Hemans) 104

'Lord May I Come?' (Siddal) 61, 65-8, 73-80, 112, 127

Lorenzo at His Desk in the Workhouse (Hunt) 222-3

'Love and Hate' (Siddal) 51, 105, 174-85, 188, 190

'Love Enthroned' (D. G. Rossetti) 62, 68-9, 72, 76

'Love-Sweetness' (D. G. Rossetti) 63, 69-70, 77-80
Lovers Listening to Music (Siddal) 44-5

'Love's Lovers' (D. G. Rossetti) 63, $71-2,76,78$

'The Lust of the Eyes' (Siddal) 36, 61-9, 73-7, 100, 207

'Lyke Wake Dirge' (border ballad) 110

Madonna and Child (Siddal) 56

'May Janet' (Swinburne) 109-10, 115, 118-19, 124-5, 130, 133-4

Monna Innominata (C. Rossetti) 8-9, 58-9

Monna Vanna (D. G. Rossetti) 209

Mother and Daughter (Webster) 59

'Night Blowing Flowers' (Hemans) 104

'Night at Sea' (Landon) 111-12

'Noble Sisters' (C. Rossetti) 105

'Now sleeps the crimson petal' (Tennyson) 173, 179

'Nuptial Sleep' (D. G. Rossetti) 63, 65, $71,77-80$

'Ode on a Grecian Urn' (Keats) 218

'O Swallow, Swallow' (Tennyson) 173

'Our enemies have fallen' (Tennyson) 184

'The Passing of Love' (Siddal) 105, 174-5, 180-5, 188, 190

'Passion and Worship' (D. G. Rossetti) $63,71,75-8$

Pippa Passes (Siddal) 16-20, 46

Poems (1870) (D. G. Rossetti) 28, 49

'The Poor Ghost' (C. Rossetti) 127, 209-10

'The Portrait' (D. G. Rossetti) 63, 69-74

Portrait of Elizabeth Siddal Reading (D. G. Rossetti) 24-6

The Princess (Tennyson) 10, 13, 131, 144, 149, 172-9, 182

Profile Portrait of Elizabeth Siddal with Irises in her Hair (D. G. Rossetti) 162

'Properzia Rossi' (Hemans) 217

'The Queen of Hearts' (C. Rossetti) 112

Rachael and Leah (D. G. Rossetti) 164

'Remember' (C. Rossetti) 127

'Repining' (C. Rossetti) 204 
Rossetti Sitting to Elizabeth Siddal

(D. G. Rossetti) 26-7

'St Agnes' Eve' (Tennyson) 200-1

'The Sea-Swallows' (Swinburne) 109-10, 117-21, 124-5, 131, 134

Self Portrait (Siddal) 41-2

'Shepherd Turned Sailor' (Siddal) 199, 228, 231-3, 238-45, 248-9

'A Silent Wood' (Siddal) 61, 64-77

Sister Helen (D. G. Rossetti) 20-1

Sister Helen (Siddal) 20-2

'A Song of the Ragged Schools of London' (Barrett Browning) 105

'Song: 'When I am Dead, My Dearest' (C. Rossetti) 127

'Songs of the Cid' (Hemans) 104

'A Sonnet is a Moment's Monument' (D. G. Rossetti) 62

Sonnets from the Portuguese (Barrett Browning) 58

'Speechless' (Siddal) 106, 110, 114-16, 120, 123-30, 133-5, 207

'The Stream's Secret' (D. G. Rossetti) 209

Study for St Agnes' Eve (Siddal) 201-4

'Sweet and low' (Tennyson) 173, 181

'Tears, idle tears' (Tennyson) 173, 189

The Eve of St Agnes (Hunt) 219-21
The Eve of St Agnes (Keats) 199, 203, 206-7, 236-51

The Eve of St Agnes (Millais) 221-2

'Thy voice is heard through rolling drums' (Tennyson) 143

'True Love' (Siddal) 100, 109-10, 113, 116, 120, 123-30, 133-5, 207

'The Twa Corbies' (border ballad) 110

'Uphill' (C. Rossetti) 9

'A Vision of Poets' (Barrett Browning) 96

A Woman and a Spectre (Siddal) 196-9, 251

'A Woman's Last Word' (Browning) 154

'A Woman's Question' (Procter) 154

'The Worm of Spindlestonheugh' (Swinburne) 109-10, 119-21, 129-35

'Worn Out' (Siddal) 199, 227-33, 237-41, 244-9

'A Year and a Day' (Siddal) 99, 106, 109, 116-20, 124, 127-30, 133-5, 207 